\title{
Unraveling the role of the ghrelin gene peptides in the endocrine pancreas
}

\author{
Riccarda Granata ${ }^{1,2}$, Alessandra Baragli ${ }^{1,2}$, Fabio Settanni ${ }^{1,2}$, Francesca Scarlatti ${ }^{1,2}$ \\ and Ezio Ghigo ${ }^{2}$
}

\footnotetext{
${ }^{1}$ Laboratory of Molecular, Cellular Endocrinology and Metabolism and ${ }^{2}$ Division of Endocrinology, Diabetology and Metabolism, Department of Internal Medicine, University of Turin, Corso Dogliotti 14, 10126 Turin, Italy

(Correspondence should be addressed to R Granata; Email: riccarda.granata@unito.it)
}

\begin{abstract}
The ghrelin gene peptides include acylated ghrelin (AG), unacylated ghrelin (UAG), and obestatin (Ob). AG, mainly produced by the stomach, exerts its central and peripheral effects through the GH secretagogue receptor type 1a (GHS-R1a). UAG, although devoid of GHS-R1a-binding affinity, is an active peptide, sharing with AG many effects through an unknown receptor. Ob was discovered as the G-protein-coupled receptor 39 (GPR39) ligand; however, its physiological actions remain unclear. The endocrine pancreas is necessary for glucose homeostasis maintenance. AG, $\mathrm{UAG}$, and $\mathrm{Ob}$ are expressed in both human and rodent pancreatic islets from fetal to adult life, and the pancreas is the major source of ghrelin in the perinatal period. GHS-R1a and GPR39 expression has been shown in $\beta$-cells and islets, as well as specific binding sites for AG, UAG, and Ob. Ghrelin colocalizes with glucagon in $\alpha$-islet cells, but is also uniquely expressed in $\varepsilon$-islet cells, suggesting a role in islet function and development. Indeed, AG, UAG, and Ob regulate insulin secretion in $\beta$-cells and isolated islets, promote $\beta$-cell proliferation and survival, inhibit $\beta$-cell and human islet cell apoptosis, and modulate the expression of genes that are essential in pancreatic islet cell biology. They even induce $\beta$-cell regeneration and prevent diabetes in streptozotocin-treated neonatal rats. The receptor(s) mediating their effects are not fully characterized, and a signaling crosstalk has been suggested. The present review summarizes the newest findings on AG, UAG, and Ob expression in pancreatic islets and the role of these peptides on $\beta$-cell development, survival, and function.
\end{abstract}

Journal of Molecular Endocrinology (2010) 45, 107-118

\section{Introduction}

Ghrelin is a 28-aminoacid peptide initially isolated from human and rat stomach as an endogenous ligand for the GH secretagogue receptor type la (GHS-R1a; Kojima et al. 1999). Ghrelin peptides exist in two major molecular forms, acylated ghrelin (AG) and unacylated ghrelin (UAG). The acylation, catalyzed by ghrelin $O$-acyltransferase (GOAT; Gutierrez et al. 2008, Yang et al. 2008), occurs on the third residue (Ser), and is essential for binding to GHS-R1a (Fig. 1), which is responsible for ghrelin GH-releasing and orexigenic central activities (Howard et al. 1996, Sun et al. 2004). Circulating ghrelin is mainly produced in the stomach; however, lower amounts have been detected in other central and peripheral tissues, including the gastrointestinal tract, pancreas, brain, pituitary gland, kidney, lung, heart, and placenta. Similarly, GHS-R1a is expressed in a variety of tissues (suggesting that
AG may target them) besides the hypothalamus and pituitary (Kojima et al. 1999, Gnanapavan et al. 2002, van der Lely et al. 2004). Indeed, AG was demonstrated to act as an autocrine/paracrine factor, regulating cell proliferation and survival, apoptosis, inflammation, cardiovascular and gastric functions, metabolism, angiogenesis, development, and reproduction (Muccioli et al. 2007, Dezaki et al. 2008, Chanoine et al. 2009, van der Lely 2009).

UAG, which circulates in amounts far greater than AG, does not bind to GHS-Rla, and is devoid of effects on GH release (van der Lely et al. 2004, Muccioli et al. 2007). Initially thought to be nonfunctional, UAG was subsequently proven to exert specific biological activities, some of which are similar to and others opposed to or independent of AG. Interestingly, AG and UAG recognize common binding sites, and exert functions in cells and tissues that do not express the GHS-R1a, implying the existence of an as yet unidentified receptor

DOI: 10.1677/JME-10-0019 Online version via http://www.endocrinology-journals.org 


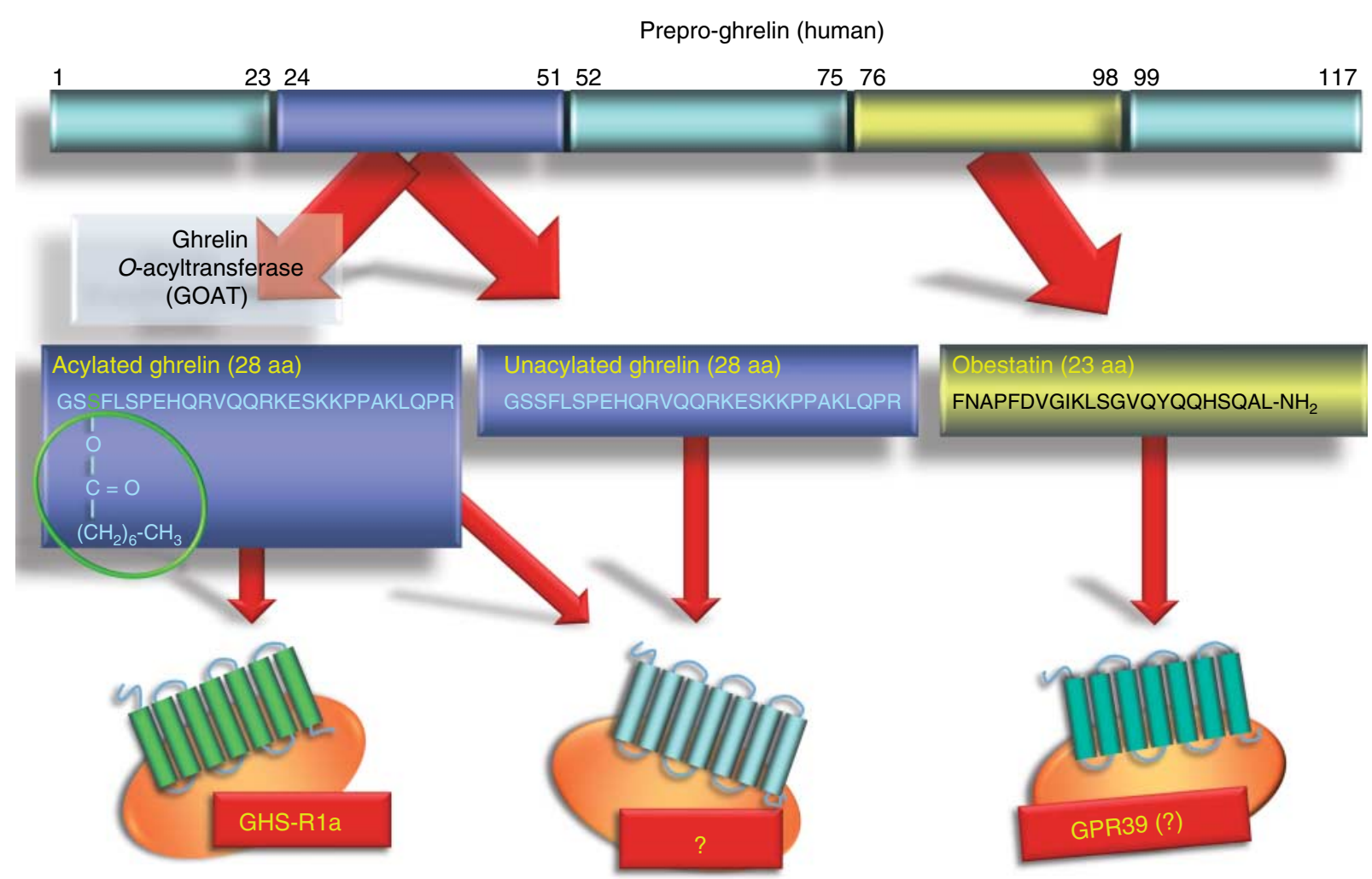

Figure 1 Ghrelin mRNA is translated into a 117-amino acid ghrelin precursor, prepro-ghrelin. The 28-aminoacid peptide ghrelin derives from cleavage of the N-terminal fragment of prepro-ghrelin. Obestatin originates from the C-terminal fragment of the ghrelin precursor. Ghrelin exists in two main forms: acylated and unacylated. Ghrelin acylation on serine 3, promoted by GOAT, is essential for binding to the GHS-R1a and for its endocrine functions. Unacylated ghrelin is devoid of GHS-R1a affinity, and its receptor remains to be identified. Obestatin was proposed as the natural ligand of the GPR39 orphan receptor; however, this finding has been questioned, and the identity of obestatin receptor(s) remains uncertain. GHS-R1a, GH secretagogue receptor type 1a; GPR39, G-protein-coupled receptor 39; GOAT, ghrelin acyl transferase.

for the ghrelin isoforms (Fig. 1; Soares \& Leite-Moreira 2008, Inhoff et al. 2009, van der Lely 2009).

The 23-aminoacid amidated peptide obestatin $(\mathrm{Ob})$ is a novel ghrelin gene product, which was identified as the G-protein-coupled receptor 39 (GPR39) ligand and claimed to be a physiological opponent of AG (Zhang et al. 2005, 2008). However, these findings have lately been questioned, and $\mathrm{Ob}$ physiological relevance remains unclear (Fig. 1; Gourcerol \& Tache 2007, Ren et al. 2008a, Tang et al. 2008). Ob is mainly produced in the stomach by the same endocrine cells as ghrelin, and at lower level in the pancreas (Granata et al. 2008, Gronberg et al. 2008, Volante et al. 2009). Central activities have been reported for $\mathrm{Ob}$, i.e. inhibition of thirst, modulation of mnemonic functions, of anxiety and sleep, but also peripheral effects. At the cellular level, Ob regulates cell proliferation and survival (Granata et al. 2008, Tang et al. 2008), and was found to stimulate GH release from rat tumor somatotrope cells (Pazos et al. 2009).

Recently, most of the interest has focused on the role played by the ghrelin gene peptides in the modulation of pancreatic function. Thus, in the present review, we will summarize the newest findings on $A G, U A G$, and Ob expression and their effects in endocrine pancreatic cells. In particular, we will consider the implication of these peptides for pancreatic $\beta$-cell development, survival, and secretory activity.

\section{$A G, U A G$, and $O b$ expression in the endocrine pancreas}

The pancreas is composed of exocrine cells essential for nutrient digestion, and of endocrine cells, regulating glucose homeostasis. The islets of Langerhans, which are the functional units of the endocrine pancreas, consist of five different cell types: glucagonsecreting alpha $(\alpha)$-cells, insulin-secreting beta $(\beta)$-cells, somatostatin-producing delta $(\delta)$-cells, pancreatic polypeptide (PP)-containing cells, and the recently identified ghrelin-producing epsilon $(\varepsilon)$-cells (Assmann et al. 2009). 
The ghrelin and GHS-R1a mRNAs and proteins have been identified in both human and rat pancreatic islets (Date et al. 2002, Dezaki et al. 2004). GHS-R1a immunoreactivity colocalizes with glucagon in most rat $\alpha$-cells and in some of the $\beta$-cells. Both ghrelin and GHS-Rla-like staining were instead detected in the same cells in the periphery of rat islets (Kageyama et al. 2005). Furthermore, in human pancreatic islets, GHS-R1a immunoreactivity partially overlaps with insulin-positive $\beta$-cells, as demonstrated by double immunofluorescence staining for both GHS-R1a and insulin (Granata et al. 2007), indicating that human $\beta$-cells might also be responsive to ghrelin stimulation. Like the two forms of ghrelin, GHS-R1a expression was shown in human and rat developing pancreatic islets, from early gestation to adult (Date et al. 2002, Chanoine \& Wong 2004, Granata et al. 2007, Ueberberg et al. 2009).

In normal rats, ghrelin-immunoreactive cells have been observed in the peripheral region of the islet of Langerhans, whereas in diabetic rats, ghrelin immunoreactivity was discerned in the central region of the islets, with a more intense staining (Adeghate \& Ponery 2002). Ghrelin and its receptor colocalization with other islet hormones are still a matter of debate. The existence of a new islet cell population expressing ghrelin was initially postulated by Wierup et al. They provided evidence for ghrelin absence from other islet endocrine cells, with the exception of a short perinatal period in rats, when a minor ghrelin cell subpopulation expressed glucagon and PP as well (Wierup et al. 2002, 2004). More recently, ghrelin and preproghrelin immunostaining have been shown to be either dependent or independent of glucagon staining, confirming the existence of at least two different ghrelin cells in the pancreas (Walia et al. 2009). The majority of ghrelinproducing cells represent a unique population, named the $\varepsilon$-cell type, which enlarges when genes essential for $\beta$-cell development are knocked down (Prado et al. $2004)$. Only one study reported $\beta$-cell restricted ghrelin expression in the human pancreas (Volante et al. 2002). Ghrelin expression in insulin-producing cells was, however, also demonstrated in rodent-derived $\beta$-cell lines (Granata et al. 2007). Interestingly, AG and UAG were found expressed both in the adult and perinatal rat pancreas (Date et al. 2002, Chanoine et al. 2006), suggesting autocrine/paracrine effects throughout the organ's development.

Consistent with the assumption that ghrelin cells represent a specific islet cell type, Ob colocalizes with ghrelin in rat pancreatic islet periphery, its distribution differing from the other islet hormones, as demonstrated by immunohistochemical and electron micropscopy studies (Zhao et al. 2008, Walia et al. 2009). Several other authors confirmed these findings in both fetal and adult human pancreas (Granata et al. 2008, Gronberg et al. 2008, Volante et al. 2009). Interestingly, although not coexpressed with insulin-producing $\beta$-cells in the pancreas, Ob secretion has been shown in human pancreatic islet cells and in the INS-1E $\beta$-cell line, suggesting that, similarly to ghrelin, $\mathrm{Ob}$ may act in the pancreas through autocrine/paracrine mechanisms (Granata et al. 2008). Besides GPR39 potentially being the receptor of Ob (Zhang et al. 2005, 2008, Dong et al. 2009), its expression has been demonstrated both in human and rodent endocrine pancreas and in $\beta$-cell lines (Holst et al. 2009, Tremblay et al. 2009), raising the possibility of GPR39 ligands directly influencing pancreatic islet activity.

GOAT has been identified as the enzyme which transfers an octanoate group to ghrelin, a modification essential for its hormonal activities (Gutierrez et al. 2008, Yang et al. 2008). Notably, both the human stomach and particularly the pancreas express high levels of GOAT mRNA. As both the ghrelin and GOAT transcripts are expressed in the pancreas, it may be hypothesized that a fine tuning of pancreatic AG versus UAG levels may take place and affect pancreatic homeostasis, with particular regard to insulin secretion (Gutierrez et al. 2008).

\section{Major genes controlling endocrine pancreatic development with respect to the ghrelin gene}

Both in the rodent and human pancreas, ghrelin levels peak at late gestation and gradually decline after birth (Wierup et al. 2002, 2004). Indeed, ghrelin mRNA and protein are detectable in the mouse pancreas at different developmental stages (Prado et al. 2004). Interestingly, ghrelin onset in the pancreas precedes by far that in the stomach, although pancreatic ghrelin cell number remains lower in adult islets (Wierup et al. 2002, 2004). Furthermore, ghrelin content is markedly elevated in fetal pancreas compared with the stomach; thus, at this stage, the pancreas and not the stomach might be the major source of ghrelin (Chanoine \& Wong 2004). With regard to Ob, although its concentration in the rat perinatal pancreas is lower than that of $\mathrm{AG}$, a correlation between insulin and $\mathrm{Ob}$ levels has been observed in the postnatal pancreas, suggesting a role for it as well (Chanoine et al. 2006). Collectively, all the above studies lead to the hypothesis of a developmental function for the ghrelin gene products.

Islet cell differentiation is the end product of complex interactions among timely activated transcription factors during pancreas organogenesis (Fig. 2). The endocrine lineage develops according to the hierarchical expression of the homeodomaincontaining transcription factor duodenal homeobox (pancreatic and duodenal homeobox 1, PDX1) in both endocrine and exocrine progenitor cells, followed 


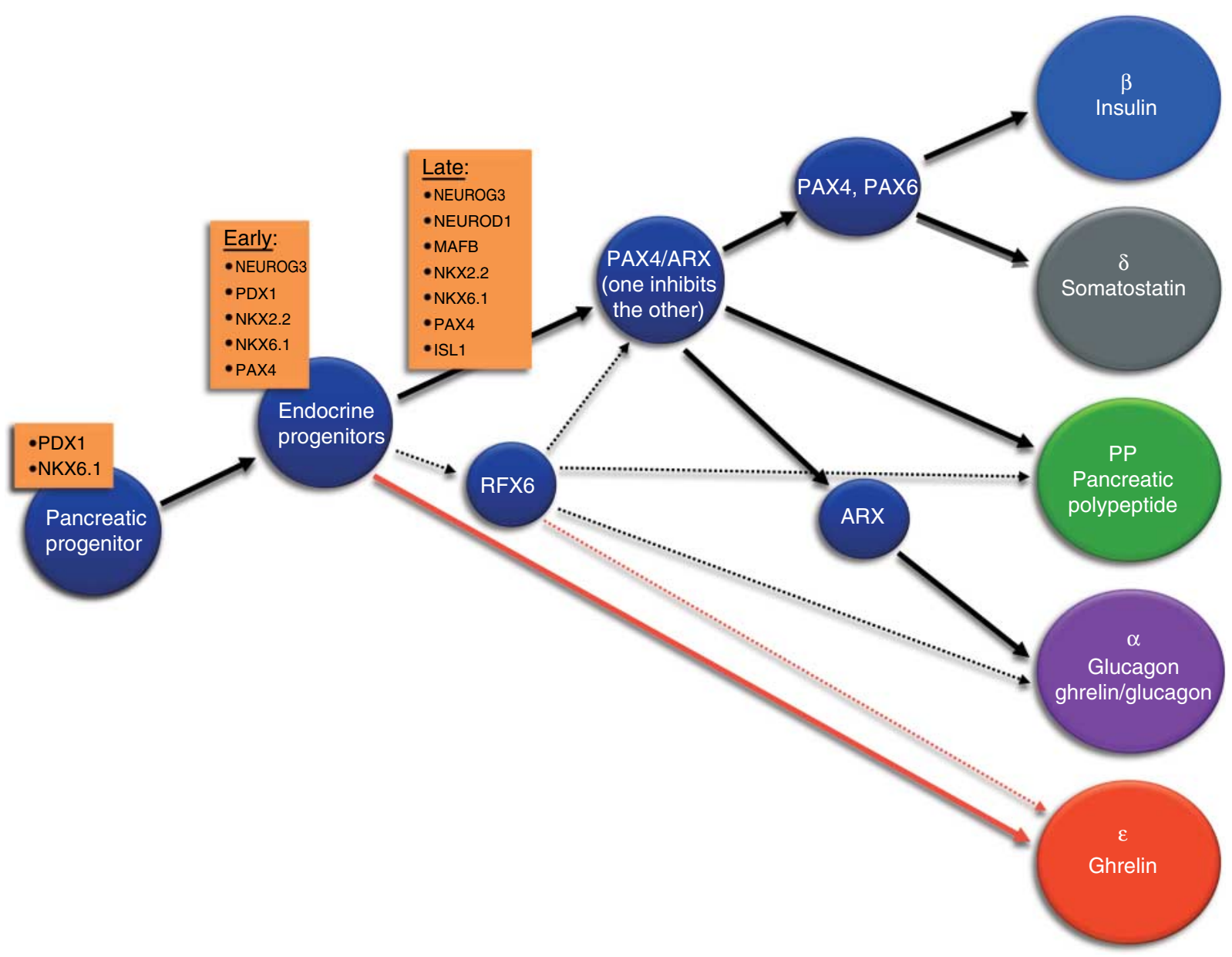

Figure 2 Simplified schematic representation of the hierarchical activation of genes involved in islet endocrine cell subtypes specification. Black arrows indicate well-established genetic paths responsible for the progression of a putative common pancreatic progenitor toward differentiation into a specialized hormone-secreting cell (Samson \& Chan 2006, Bonal \& Herrera 2008). Red arrows indicate the hypothesized paths guiding progenitors toward the ghrelin/obestatin-secreting cells fate (Prado et al. 2004, Heller et al. 2005, Bonal \& Herrera 2008, Wang et al. 2008, Soyer et al. 2010), while dotted arrows refer to the recently highlighted roles of the transcription factor Rfx6 in pancreatic cell lineage specification (Soyer et al. 2010). Please note that the path followed by the $\varepsilon$-cell population becomes independent from the one leading to the mixed ghrelin +/glucagon + population at relatively early stages of pancreatic progenitor differentiation (Heller et al. 2005). NEUROG3, neurogenin 3; PDX1, pancreatic and duodenal homeobox 1; NKX2.2, NK2 homeobox 2; NKX6.1, NK6 homeobox 1; PAX4, paired box gene 4; PAX6, paired box gene 6; NEUROD1, neurogenic differentiation 1; RFX6, regulatory factor X, 6; ARX, aristaless-related homeobox; ISL1, islet1.

by the basic helix-loop-helix transcription factors neurogenin 3 (NEUROG3) and the targeted NEUROD1, which initiate the endocrine progenitor cascade. The subsequential turning-on of transcription factors such as NK-homeobox factor 2.2 (NKX2.2), paired box gene 4 (PAX4), or NK-homeobox factor 6.2 (NKX6.2) is essential for cell-type specification in $\beta$-, $\delta$ - (NKX2.2 and PAX4), PP- (NKX2.2), and $\alpha$-cells (NKX6.2, PAX6). But while PDX1 expression persists in the mature $\beta$-cell participating in insulin gene transcription, most of the above transcription factors tend to be down-regulated as differentiation progresses (Samson \& Chan 2006, Oliver-Krasinski et al. 2009). Moreover, depending on the developmental day and on the cell type, these factors may function as repressors or activators of downstream genes, as is the case for NKX2.2.

In mice lacking NKX2.2 ( $N k \times 2.2-/-)$, all $\beta$-cells and most $\alpha$-cells are replaced with $\varepsilon$-cells; therefore, it was proposed that the ghrelin-producing $\varepsilon$-cells may derive from the same precursor of insulin-producing $\beta$-cells (Prado et al. 2004). Similar results were obtained in PAX4 mutant mice, suggesting that both genes negatively influence ghrelin expression in favor of insulin and glucagon (Prado et al. 2004). Recently, a similar increase in $\varepsilon$-cells at the expense of $\alpha$ - and $\beta$-cells was shown to result from the knockdown of the transcription factor Irx3a in zebrafish (Ragvin et al. 2010). Nevertheless, while PAX4 was confirmed to be a transcriptional 
repressor of the ghrelin gene in pancreatic endocrine progenitors (Wang et al. 2008), a recent report demonstrated $N k \times 2.2-/-$ direct binding to a promoter region of the ghrelin gene through which it fosters its transcription (Hill et al. 2010). Thus, in $N k \times 2.2-/-$ mice, the cause of pancreatic islet population altered assortment may not be the lack of NKX2.2 repressive activity on the ghrelin gene. Rather, a more complex change in the regulatory mechanisms of the ghrelin gene transcription might have occurred, which needs further investigation. The $N k \times 2.2-/-$ and Neurod1-/ - double knockout mice are only one example of how the interaction among a multiplicity of transcription factors determines islet cell type specification: compared with the $N k x 2.2-/-$ single knockout mice, the double knockout mice show reduced $\varepsilon$ - and increased $\alpha$-cell number, suggesting that the $\alpha$-cell population is restored at the expense of the ghrelinproducing cells, and that NEUROD1 may be a determinant in $\varepsilon$-cell type specification (Chao et al. 2007). Only recently, a novel winged helix NEUROG3-dependent transcription factor was identified in zebrafish, regulatory factor $\mathrm{X} 6$ ( $\mathrm{Rf} \times 6)$, which is required for the differentiation of pancreatic progenitors into glucagon, ghrelin-, and somatostatin-secreting cells (Soyer et al. 2010). The loose organization of $\beta$-cells in $\mathrm{Rf} x 6$ morphants suggests that $\mathrm{Rf} x 6$ controls genes responsible for $\beta$-cell clustering, and, perhaps, that glucagon, ghrelin, or somatostatin are somehow involved in this process. Based on all the above findings and on evidence that ghrelin regulates cell differentiation of several tissues (Kim et al. 2005, Filigheddu et al. 2007), ghrelin null mice were expected to have impaired endocrine pancreas development. However, ghrelin null mice showed no perturbation of islet cell populations and structure, indicating that ghrelin is not essential for normal islet formation. In addition, the elimination of ghrelin in $N k \times 2.2-/-$ islets does not restore $\alpha$ - and $\beta$-cell populations, confirming that the event responsible for the loss of insulin- and glucagon-producing cells in $N k \times 2.2$ null mice is not the upregulation of ghrelin (Hill et al. 2009).

In the human fetus, ghrelin cells were shown to possess unique ultrastructural features (Wierup \& Sundler 2005), and ontogenic and morphogenetic pattern different from that of other islet cells (Andralojc et al. 2009). However, at present, the temporal and cellular activation of the net of genes participating in $\varepsilon$-cell specification (with respect to the other hormone secreting cells) is still far from being completely unraveled (Fig. 2). Part of ghrelin-producing islet cells derive from NEUROG3expressing precursors and require NEUROG3 activity for their development, a transcription factor necessary for the differentiation of the endocrine precursor into mature cells (Heller et al. 2005). NEUROG3-dependent genes $A R X$ and $P A X 4$, although playing unique roles in shaping $\alpha$-cell destiny, including one of the population coexpressing ghrelin and glucagon, do not participate in the $\varepsilon$-lineage specification. On the other side, $\varepsilon$-cell formation is antagonized by PAX6, which is also downstream of NEUROG3. PAX6-deficient mice, in fact, exhibit an excess of $\varepsilon$-cells at the expenses of $\alpha$-cells (Heller et al. 2005). Thus, apart from those mentioned, most of the genes determining the progression from the earliest progenitors to the $\varepsilon$-cells population remain almost completely obscure (Fig. 2).

\section{Survival effects of $A G, U A G$, and $O b$ in $\beta$-cells and human pancreatic islets}

AG has been shown to promote $\beta$-cell regeneration and to increase insulin expression and secretion in newborn rats treated with streptozotocin (STZ; Irako et al. 2006), a compound traditionally used to study pancreatic regeneration which specifically induces $\beta$-cell destruction (Yamamoto et al. 1981). The same protective effects against STZ-induced diabetes in newborn rats were recently demonstrated for UAG and $\mathrm{Ob}$ (Granata et al. 2010). Indeed, in the pancreas of STZ-treated rats $A G$, UAG and $\mathrm{Ob}$ increase insulin expression and secretion, as well as $P d x 1$ mRNA (Irako et al. 2006, Granata et al. 2010), which is essential for insulin transcription and maintenance of $\beta$-cell mass (Ackermann \& Gannon 2007). UAG and $\mathrm{Ob}$ even increase the area and number of pancreatic islets in STZ-treated rats and reduce the expression of the $B c l 2$ antiapoptotic gene (Granata et al. 2010).

Both AG and UAG promote HIT-T15 and INS-1E $\beta$-cell proliferation, and inhibit apoptotic events induced by serum starvation and treatment with cytokines (Granata et al. 2006, 2007), a major cause of $\beta$-cell loss particularly in type 1 diabetes, but also in type 2 diabetes (MandrupPoulsen 2001). These effects involve a receptor differing from the AG canonical receptor, as demonstrated by the absence of both GHS-R1a mRNA and protein on HIT-T15 cells, and by evidence of AG/UAG common high-affinity binding sites on these cells. The signaling pathways elicited by AG and UAG stimulation involve the recruitment of $\mathrm{G}_{\mathrm{s}} \alpha$ protein-coupled receptor/adenylyl cyclase $/ 3^{\prime}, 5^{\prime}$-cAMP/protein kinase A pathway, the activation of phosphatidylinositol-3 kinase (PI3K)/AKT, and extracellular signal-regulated kinase (ERK) $1 / 2$ (Granata et al. 2007; Fig. 3), all of which control $\beta$-cell survival, antiapoptotic, and proliferative effects, and ultimately, insulin secretion (Jhala et al. 2003, Costes et al. 2006).

Either AG or UAG is expressed and secreted from HIT-T15 $\beta$-cells, and treatment with antighrelin antibodies increases apoptosis, supporting the survival potential of ghrelin. Also, AG and UAG reduce cytokineinduced nitric oxide (NO) production (Granata et al. 2007), which is involved in $\beta$-cell dysfunction and death 


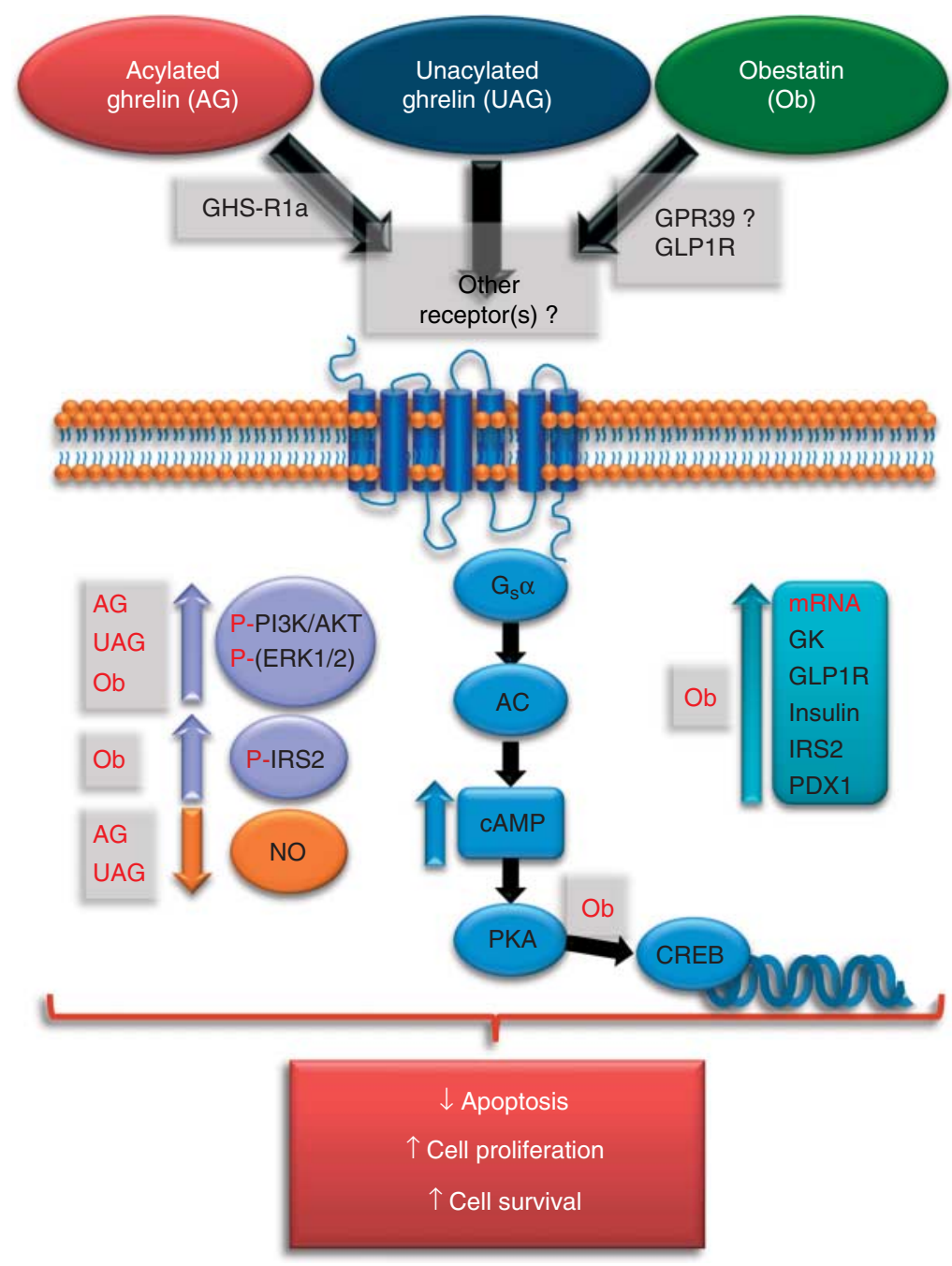

Figure 3 Main intracellular signaling pathways associated with the survival effects of the ghrelin gene peptides in $\beta$-cells and human pancreatic islets subjected to serum deprivation or cytokine treatment. Presumably, AG, UAG, and Ob bind to a GPCR which, through the $G_{s} \alpha$ subunit of the associated $G$-protein complex, stimulates $A C$, resulting in increased cAMP production. The involved receptors are GHS-R1a for AG, an unknown receptor(s) for UAG, and likely GPR39 or GLP1R for Ob. In addition, the existence of common receptor(s) for the three peptides has been suggested. In the case of Ob-induced cAMP elevation, the cAMP-dependent enzyme PKA phosphorylates and activates the transcription factor CREB. The effect of AG and UAG on CREB phosphorylation remains to be studied. The antiapoptotic, proliferative, and survival effects of AG, UAG, and Ob involve the canonical PI3K/AKT and MAPK (ERK1/2) pathways. Furthermore, AG and UAG also decrease NO, which has been associated with $\beta$-cell dysfunction and death; this effect was not examined for $\mathrm{Ob}$. All these events contribute to reduced apoptosis, increased $\beta$-cell, and human islet cell proliferation and survival. Treatment with the ghrelin gene peptides determines increased glucose-induced insulin secretion in both rat $\beta$-cells and human pancreatic islets. Both the survival and insulinotropic actions of $\mathrm{Ob}$ are supported by its capacity to increase IRS2 phosphorylation and IRS2, PDX1, GK, and GLP1R mRNAs in human islets. (AC, adenylyl cyclase; CREB, cAMP response element-binding protein; ERK1/2, extracellular signalregulated kinase 1/2; GHS-R1a, GH secretagogue receptor type 1a, GK, glucokinase; GLP1R, glucagon-like peptide-1 receptor; GPR39, G-protein-coupled receptor 39; $\mathrm{G}_{\mathrm{s}} \alpha$, G-coupled receptor stimulatory protein; IRS2, insulin receptor substrate-2; NO, nitric oxide; PDX1, pancreatic and duodenal homeobox-1; PI3K, phosphatidylinositol 3-kinase; PKA, protein kinase $A$. 
(McCabe et al. 2006). Subsequently, others confirmed the antiapoptotic effects of AG in HIT-T15 $\beta$-cells under serum deprivation or treatment with doxorubicin. The pathways involved in these effects were the same as those previously observed; in addition, AG increased the antiapoptotic protein BCL2, decreased the proapoptotic protein $\mathrm{BAX}$, and prevented cytochrome $c$ release from mitochondria (Zhang et al. 2007). Moreover, AG was recently found to prevent lipotoxicity-induced apoptosis in MIN6 $\beta$-cells through the activation of protein kinase $\mathrm{B}$, inhibition of jun $\mathrm{N}$-terminal kinase (JNK) and of the mitochondrial pathway, and reduction of the nuclear translocation of the transcription regulator forkhead box O1 (FOXO1; Wang et al. 2010a,b).

In human islets, similarly to $\beta$-cell lines, both AG and UAG recognize still unknown common specific binding sites on cell membranes, and GHS-R1a partially colocalizes with some insulin-expressing cells (Granata et al. 2007). Likely through these receptors, AG and UAG elicit protective effects similar to those described in pancreatic-derived cell lines against serum starvationand cytokine-induced apoptosis (Fig. 3).

Thus, based on the above findings and on the presence of the ghrelin-producing $\varepsilon$-cell population within the islet, the regulation of $\beta$-cell function and survival by the endogenous ghrelin gene products appear to be a most likely event.

It was recently reported that in $90 \%$ pancreatectomized rats that showed high hyperlgycemia, and decreased $\beta$-cell mass and insulin levels, AG administration strongly reduced glucose levels, increased insulin-producing $\beta$-cell number, and insulin secretion. On the contrary, ghrelin receptor antagonist administration in pancreatectomized rats worsens glucose levels and $\beta$-cell mass, in support of the involvement of GHS$\mathrm{R} 1 \mathrm{a}$ or of endogenous ghrelin in islet cell survival and function (Kerem et al. 2009).

Like ghrelin, Ob promotes $\beta$-cell proliferation, and reduces cell death and apoptosis induced by serum starvation and cytokine synergism (Granata et al. 2008). Furthermore, $\mathrm{Ob}$ is secreted by $\beta$-cells and human islets (Granata et al. 2008). Owing to the uncertainty of GPR39 being the receptor for $\mathrm{Ob}$ (Gourcerol \& Tache 2007), binding studies were conducted demonstrating that $\mathrm{Ob}$ recognizes specific sites on HIT-T15 and INS-1E $\beta$-cell membranes, and also interacts with receptors recognized by AG, suggesting crosstalk among the ghrelin gene peptides to produce their pancreatic actions. The signaling pathways involved in $\mathrm{Ob}$ antiapoptotic effects are also similar to ghrelin. Indeed, $\mathrm{Ob}$ increases cAMP levels, and promotes ERK1 / 2 and PI3K/AKT phosphorylation (Fig. 3), while the inhibition of these pathways reduces $\mathrm{Ob}$ antiapoptotic effects. As Ob survival actions and signaling mechanisms in $\beta$-cells are similar to those elicited by the receptor of glucagon-like peptide 1 (GLP1R), it was hypothesized that Ob might also trigger the GLP1R signaling cascade in $\beta$-cells. Indeed, $\mathrm{Ob}$ increases GLP1R mRNA in INS-1E cells and promotes survival to an extent equal to that of the GLP1 analog exendin-4 (Ex-4), and its survival action is prevented by the GLP1R antagonist Ex-9. Also, like Ex-4, Ob increases gene expression and phosphorylation of insulin receptor substrate 2 (IRS2; Granata et al. 2008), which is implicated in either the insulin receptor or GLP1R signaling to regulating $\beta$-cell survival and insulin secretion (Park et al. 2006). These findings are strengthened by evidence for $\mathrm{Ob}$ ability to bind the GLP1R, although at lower affinity than its natural ligand GLP1 or its antagonist Ex-9 (Granata et al. 2008).

$\mathrm{Ob}$ is secreted by human islet cells and, as already mentioned, is expressed in both fetal and adult human islets, colocalizing with ghrelin, likely in $\varepsilon$-cells, but not with other pancreatic hormones (Granata et al. 2008, Gronberg et al. 2008, Volante et al. 2009). Ob treatment of human islets promotes the phosphorylation of cAMP response element-binding protein, required for the maintenance of glucose homeostasis and $\beta$-cell survival (Jhala et al. 2003), and decreases the phosphorylation of Src, whose expression in $\beta$-cells has been related to an inhibitory role on $\mathrm{Ca}^{2+}$-dependent insulin secretion (Cheng et al. 2007). Furthermore, in human islets, it upregulates PDX1, IRS2, and GLP1R mRNAs together with glucokinase mRNA, a glucose sensor for insulin secretion which also regulates $\beta$-cell mass and function (Terauchi et al. 2007; Fig. 3). Thus, in human islets, $\mathrm{Ob}$ elicits survival and antiapoptotic effects resembling those observed in $\beta$-cells, involving identical signaling pathways. In agreement with this, a recent report demonstrated that in rats, $\mathrm{Ob}$ reduces the damage severity of cerulein-induced acute pancreatitis, partly through improving pancreatic blood flow, by inhibiting the proinflammatory cytokine interleukin- $1 \beta$ release and partly by increasing pancreatic cell viability (Ceranowicz et al. 2009). Therefore, like ghrelin, $\mathrm{Ob}$ is secreted by $\beta$-cells, and acts on them and on their surroundings, suggesting that the endogenous peptide might be part of pancreatic hormones autocrine/paracrine systems.

\section{Effect of AG, UAG, and Ob on insulin secretion in pancreatic islets and $\beta$-cells}

The role of the ghrelin gene-derived peptides in the regulation of insulin secretion and insulin action remains a controversial topic. AG, UAG, and $\mathrm{Ob}$ have been shown to either stimulate or inhibit insulin secretion, depending upon the experimental condition (Salehi et al. 2004, Sun et al. 2007, Dezaki et al. 2008, Soares \& Leite-Moreira 2008).

In rat $\beta$-cells, $A G$ was found to increase cytosolic free $\mathrm{Ca}^{2+}$ concentration, and an insulinotropic effect of the peptide was observed in isolated rat pancreatic islets 
(Date et al. 2002). Similarly, AG increases insulin secretion from the pancreas of both normal and diabetic rats, at concentrations ranging from $10^{-12}$ to $10^{-6} \mathrm{M}$ (Adeghate \& Ponery 2002). In pancreatectomized rats, administration of AG increases insulin positive $\beta$-cell number and plasma insulin levels (Kerem et al. 2009). Similarly, in newborn rats treated with STZ, either AG, UAG, or Ob increase $\beta$-cell mass and pancreatic insulin expression and secretion from $\beta$-cells (Irako et al. 2006, Granata et al. 2010). In rat INS-1E $\beta$-cells, both AG and UAG stimulate insulin release dose dependently in the nanomolar range. AG insulinotropic effect in $\beta$-cells may involve GHS-R1a, as indicated by experiments performed in the presence of GHS-R1a antagonists, whereas for UAG, the existence of a different receptor mediating its effect was proposed (Gauna et al. 2006). Accordingly, both AG and UAG were found to increase glucose-induced insulin secretion in HIT-T15 $\beta$-cells, which do not express the GHS-R1a, suggesting the existence of a different receptor mediating the effects of both peptides (Granata et al. 2007).

On the other side, GHS-Rla blockade in isolated rat islets using specific antagonists or through AG inactivation using an antiserum, enhanced glucose-induced insulin release, and intracellular $\mathrm{Ca}^{2+}$ concentration. Interestingly, whereas relatively high concentration of AG $\left(10^{-8} \mathrm{M}\right)$ suppressed insulin release, low concentrations could not (Dezaki et al. 2004). Later, the same authors showed that both AG and UAG are released from pancreatic islets, and that AG, but not UAG, reduces glucose-induced insulin release (Dezaki et al. 2006). Ghrelin knockout mice were found to escape high-fat diet-induced glucose intolerance because of enhanced insulin release; however, the density and average size of the islets were not significantly different between wild-type and ghrelin knockout mice (Dezaki et al. 2006). As opposed to the previously mentioned studies, these latter ones indicate that ghrelin serves as a downward regulator of insulin release and consequently upward regulator of glycemia. The insulinostatic effects of endogenous and exogenous ghrelin are blunted in rat islets pretreated with pertussis toxin, a specific inhibitor of $G_{i}$ and $G_{o}$ subtypes of trimeric GTP-binding proteins (Dezaki et al. 2007), suggesting signaling through an inhibitory GPR. Interestingly, in brain, pancreas and $\beta$-cell line, AG induces the expression of $\beta$-cell autoantigen for type 1 diabetes (IA-2 $\beta$ ). AG administration or overexpression of IA-2 $\beta$ inhibits glucose-stimulated insulin secretion in $\beta$-cells, while the downregulation of IA- $2 \beta$ expression by RNA interference reduced AG inhibitory effects on insulin release, suggesting a functional link among AG, IA-2 $\beta$, and insulin secretion (Doi et al. 2006).

In keeping with the above findings, other authors reported the inhibitory effects of exogenous AG on insulin secretion in isolated mouse pancreas (Egido et al. 2002), in mouse and rat isolated islets (Colombo et al. 2003, Reimer et al. 2003, Qader et al. 2008), and in $\beta$-cell lines (Wierup et al. 2004).

It has recently been reported that, at a concentration ten times higher than that of AG, UAG abolishes the inhibitory effect of AG on insulin secretion from mouse and rat pancreatic islets, likely interacting with a receptor other than GHS-R1a (Qader et al. 2008). The same group previously showed that in rat pancreatic islets, AG reduces insulin secretion while increasing glucagon release and NO production (Qader et al. 2005).

Transgenic mice overexpressing ghrelin under the rat insulin II promoter (RIP-GTg) had a pancreatic UAG content that was 1000 times higher than the control littermates. Such mice showed reduced glucosestimulated insulin secretion and lower blood glucose levels and triglyceride levels during insulin tolerance test. Insulin secretion from isolated islets was instead indistinguishable from that of nontransgenic littermates (Iwakura et al. 2005). These results imply that UAG, differently from AG, has a positive influence on insulin sensitivity.

The understanding of effects of $\mathrm{Ob}$ on insulin secretion from pancreatic $\beta$-cell lines and pancreatic islets is still limited and controversial, as either stimulation (Granata et al. 2008, 2010) or inhibition (Qader et al. 2008, Ren et al. 2008b, Unniappan et al. 2008) has been reported, based also on the peptide concentrations used in the experiments. In the perfused rat pancreas, $\mathrm{Ob}$ potentiates glucose-induced insulin release and, when infused at a high concentration, it inhibits glucose-induced insulin release. Furthermore, $\mathrm{Ob}$ potentiates the insulin responses elicited by arginine and tolbutamide (Egido et al. 2008).

$\mathrm{Ob}$ was initially identified as the GPR39 ligand (Zhang et al. 2005); however, this finding has been questioned recently, and the receptor for $\mathrm{Ob}$ has yet to be determined (Gourcerol \& Tache 2007, Tang et al. 2008). Interestingly, isolated, perfused islets from GPR39 null mice have recently been shown to secrete less insulin in response to glucose stimulation than islets from wild-type littermates (Holst et al. 2009). Moreover, GPR39 null mice fed with either a low-fat/ high-sucrose or high-fat/high-sucrose diet show decreased serum insulin levels during an oral glucose tolerance test in the face of unchanged insulin tolerance (Tremblay et al. 2009), suggesting that GPR39 is required for insulin secretion and may be a potential target for the treatment of diabetes. Hypothesizing that GPR39 is the Ob receptor, these findings would be in agreement with the stimulatory effects of $\mathrm{Ob}$ observed in $\beta$-cell lines and human pancreatic islets (Granata et al. 2008). The Ob positive effect on insulin secretion is further supported by its capacity to bind to GLP1R (Granata et al. 2008), which 
mediates the insulinotropic effects of GLP1 and its analog Ex-4 (Drucker 2006).

By now it should be apparent that all three peptides influence pancreatic function at multiple levels. Beside the recruitment of distinct receptors, part of their effects may also be explained by promiscuous receptor coupling to G-proteins. This has already been demonstrated for GHS-Rla (Muccioli et al. 2007), for GRP39 (Holst et al. 2007), and GLP1R (Montrose-Rafizadeh et al. 1999), although it has not been specifically investigated in endocrine pancreatic cells. Only indirect evidence suggests that AG/UAG common unknown receptor expressed in $\beta$-cells could potentially activate $\mathrm{G}_{\mathrm{i}}$-dependent pathways (Dezaki et al. 2007) as well as $\mathrm{G}_{\mathrm{s}}$-dependent ones (Granata et al. 2007).

\section{Concluding remarks}

Since ghrelin has joined the pool of 'pancreatic hormones' as a result of the pancreatic e-cell population discovery, much of the interest has focused on implications for diabetes. Indeed, all three ghrelin gene-derived peptides seem to participate in glucose balance by directly influencing insulin secretion. Nevertheless, as both AG and UAG have been shown to either stimulate or inhibit insulin secretion depending upon the experimental condition, the effective role of the ghrelin gene-derived peptides in the regulation of insulin secretion and action remains controversial. The only certain evidence is that systemic AG infusion elevates blood glucose level, while UAG does not. It is now well accepted that AG and UAG pleiotropic activities depend on their affinity for multiple receptors, some of which they share, but are still unknown, some others which they do not, as with GHS-R1a, which probably accounts for most of the differences. For Ob, the studies in this sense are still too limited to draw any conclusions. It seems clear that it stimulates insulin secretion in vitro, partly through the binding to GLP1R, possibly but not certainly to GPR39, which may or may not be the high-affinity binding site.

AG, UAG and Ob, GOAT, GHS-R1a, AG/UAG common uncloned receptors and Ob-binding sites, are all expressed at least in rodent pancreatic islets from early gestation to adult. Thus, hypothesizing the presence of a ghrelin autocrine pancreatic system is consequential. Indeed, in pancreatic islets and derived $\beta$-cell lines, AG, UAG, and Ob elicit similar protective effects against serum starvation- and cytokine-induced apoptosis in vitro, while they promote $\beta$-cell proliferation/regeneration and increase insulin expression and secretion in STZ-treated newborn rats. Although the recruited intracellular signaling pathways appear to be comparable, the direct involvement of the GLP1R machinery may favor $\mathrm{Ob}$ for therapeutic exploitation, as it has been for Ex-4 (Exenatide). The same possibility accounts for UAG, which was found to counteract many of the AG diabetogenic effects.

Concerning pancreatic development, it is now established that $\varepsilon$-cells are present in the pancreas in large numbers during fetal life and early postnatal period, being reduced after birth. The early appearance of both peptides and receptors might imply an involvement in pancreas ontogenesis. However, at first glance, the ghrelin gene $\mathrm{KO}$ mice have no altered phenotype in this sense, suggesting that the three peptides are not essential for pancreas development. Nevertheless, it cannot be excluded that the timely and/or cellular-restricted selective secretion of the three peptides during pancreas development shapes the phenotype of cellular populations, which remain quiescent in normal conditions, but may be recruited or sensitized at need, i.e. in pathological settings involving pancreas inflammation and $\beta$-cell dysfunction.

In conclusion, many questions remain unanswered. Among these, may ghrelin secretion within the pancreas influence the physiology of other islet cell populations or vice versa? If so, what are the mechanisms involved in these effects? Which/how many receptors mediate protective effects of these peptides? What would be the role of changes in pancreatic ghrelin production under pathological conditions?

\section{Declaration of interest}

The authors declare that there is no conflict of interest that could be perceived as prejudicing the impartiality of the research reported.

\section{Funding}

This work is supported by grants to R Granata (Piedmonte Region, Ricerca Finalizzata 2007, 2009; University of Turin, Ex-60\% 2007), by grants to E Ghigo (Sixth EC Program LSHM-CT-2003-503041, CIPE 2004, MIUR 2005, FIN-60\% 2006 and 2007), by the Compagnia di San Paolo and the SMEM Foundation, Turin, Italy.

\section{Acknowledgements}

The authors wish to thank the European Consortium for Islet Transplantation (ECIT) 'Islets for Research Distribution Program', Transplant Unit, Scientific Institute San Raffaele, Vita-Salute University, Milan, Italy.

\section{References}

Ackermann AM \& Gannon M 2007 Molecular regulation of pancreatic beta-cell mass development, maintenance, and expansion. Journal of Molecular Endocrinology 38 193-206. (doi:10.1677/JME-06-0053) 
Adeghate E \& Ponery AS 2002 Ghrelin stimulates insulin secretion from the pancreas of normal and diabetic rats. Journal of Neuroendocrinology 14 555-560. (doi:10.1046/j.1365-2826.2002. 00811.x)

Andralojc KM, Mercalli A, Nowak KW, Albarello L, Calcagno R, Luzi L, Bonifacio E, Doglioni C \& Piemonti L 2009 Ghrelinproducing epsilon cells in the developing and adult human pancreas. Diabetologia 52 486-493. (doi:10.1007/s00125-0081238-y)

Assmann A, Hinault C \& Kulkarni RN 2009 Growth factor control of pancreatic islet regeneration and function. Pediatric Diabetes 10 14-32. (doi:10.1111/j.1399-5448.2008.00468.x)

Bonal C \& Herrera PL 2008 Genes controlling pancreas ontogeny. International Journal of Developmental Biology 52 823-835. (doi:10. $1387 /$ ijdb.072444cb)

Ceranowicz P, Warzecha Z, Dembinski A, Cieszkowski J, Dembinski M, Sendur R, Kusnierz-Cabala B, Tomaszewska R, Kuwahara A \& Kato I 2009 Pretreatment with obestatin inhibits the development of cerulein-induced pancreatitis. Journal of Physiology and Pharmacology 60 95-101.

Chanoine JP \& Wong AC 2004 Ghrelin gene expression is markedly higher in fetal pancreas compared with fetal stomach: effect of maternal fasting. Endocrinology 145 3813-3820. (doi:10. $1210 /$ en.2004-0053)

Chanoine JP, Wong AC \& Barrios V 2006 Obestatin, acylated and total ghrelin concentrations in the perinatal rat pancreas. Hormone Research 66 81-88. (doi:10.1159/000093585)

Chanoine JP, De Waele K \& Walia P 2009 Ghrelin and the growth hormone secretagogue receptor in growth and development. International Journal of Obesity 33 (Supplement 1) S48-S52. (doi:10.1038/ijo.2009.17)

Chao CS, Loomis ZL, Lee JE \& Sussel L 2007 Genetic identification of a novel NeuroD1 function in the early differentiation of islet alpha, PP and epsilon cells. Developmental Biology 312 523-532. (doi:10.1016/j.ydbio.2007.09.057)

Cheng H, Straub SG \& Sharp GW 2007 Inhibitory role of Src family tyrosine kinases on $\mathrm{Ca}^{2+}$-dependent insulin release. American Journal of Physiology. Endocrinology and Metabolism 292 E845-E852. (doi:10.1152/ajpendo.00103.2006)

Colombo M, Gregersen S, Xiao J \& Hermansen K 2003 Effects of ghrelin and other neuropeptides (CART, MCH, orexin A and B, and GLP-1) on the release of insulin from isolated rat islets. Pancreas 27 161-166. (doi:10.1097/00006676-200308000-00009)

Costes S, Broca C, Bertrand G, Lajoix AD, Bataille D, Bockaert J \& Dalle S 2006 ERK1 / 2 control phosphorylation and protein level of cAMP-responsive element-binding protein: a key role in glucose-mediated pancreatic beta-cell survival. Diabetes $\mathbf{5 5}$ 2220-2230. (doi:10.2337/db05-1618)

Date Y, Nakazato M, Hashiguchi S, Dezaki K, Mondal MS, Hosoda H, Kojima M, Kangawa K, Arima T, Matsuo H et al. 2002 Ghrelin is present in pancreatic alpha-cells of humans and rats and stimulates insulin secretion. Diabetes 51 124-129. (doi:10.2337/ diabetes.51.1.124)

Dezaki K, Hosoda H, Kakei M, Hashiguchi S, Watanabe M, Kangawa K \& Yada T 2004 Endogenous ghrelin in pancreatic islets restricts insulin release by attenuating $\mathrm{Ca}^{2+}$ signaling in beta-cells: implication in the glycemic control in rodents. Diabetes 53 3142-3151. (doi:10.2337/diabetes.53.12.3142)

Dezaki K, Sone H, Koizumi M, Nakata M, Kakei M, Nagai H, Hosoda H, Kangawa K \& Yada T 2006 Blockade of pancreatic islet-derived ghrelin enhances insulin secretion to prevent highfat diet-induced glucose intolerance. Diabetes 55 3486-3493. (doi:10.2337/db06-0878)

Dezaki K, Kakei M \& Yada T 2007 Ghrelin uses $\mathrm{G} \alpha_{\mathrm{i} 2}$ and activates voltage-dependent $\mathrm{K}^{+}$channels to attenuate glucose-induced $\mathrm{Ca}^{2+}$ signaling and insulin release in islet beta-cells: novel signal transduction of ghrelin. Diabetes 56 2319-2327. (doi:10. 2337/db07-0345)
Dezaki K, Sone H \& Yada T 2008 Ghrelin is a physiological regulator of insulin release in pancreatic islets and glucose homeostasis. Pharmacology and Therapeutics 118 239-249. (doi:10.1016/j.pharmthera.2008.02.008)

Doi A, Shono T, Nishi M, Furuta H, Sasaki H \& Nanjo K 2006 IA-2beta, but not IA-2, is induced by ghrelin and inhibits glucose-stimulated insulin secretion. PNAS 103 885-890. (doi:10.1073/pnas.0502470102)

Dong XY, He JM, Tang SQ, Li HY, Jiang QY \& Zou XT 2009 Is GPR39 the natural receptor of obestatin? Peptides 30 431-438. (doi:10.1016/j.peptides.2008.09.022)

Drucker DJ 2006 The biology of incretin hormones. Cell Metabolism 3 153-165. (doi:10.1016/j.cmet.2006.01.004)

Egido EM, Rodriguez-Gallardo J, Silvestre RA \& Marco J 2002 Inhibitory effect of ghrelin on insulin and pancreatic somatostatin secretion. European Journal of Endocrinology 146 241-244. (doi:10.1530/eje.0.1460241)

Egido EM, Hernandez R, Marco J \& Silvestre RA 2008 Effect of obestatin on insulin, glucagon and somatostatin secretion in the perfused rat pancreas. Regulatory Peptides 152 61-66. (doi:10. 1016/j.regpep.2008.08.003)

Filigheddu N, Gnocchi VF, Coscia M, Cappelli M, Porporato PE, Taulli R, Traini S, Baldanzi G, Chianale F, Cutrupi S et al. 2007 Ghrelin and des-acyl ghrelin promote differentiation and fusion of C2C12 skeletal muscle cells. Molecular Biology of the Cell 18 986-994. (doi:10.1091/mbc.E06-05-0402)

Gauna C, Delhanty PJ, van Aken MO, Janssen JA, Themmen AP, Hofland LJ, Culler M, Broglio F, Ghigo E \& van der Lely AJ 2006 Unacylated ghrelin is active on the INS-1E rat insulinoma cell line independently of the growth hormone secretagogue receptor type $1 \mathrm{a}$ and the corticotropin releasing factor 2 receptor. Molecular and Cellular Endocrinology 251 103-111. (doi:10.1016/j.mce.2006.03.040)

Gnanapavan S, Kola B, Bustin SA, Morris DG, McGee P, Fairclough P, Bhattacharya S, Carpenter R, Grossman AB \& Korbonits M 2002 The tissue distribution of the mRNA of ghrelin and subtypes of its receptor, GHS-R, in humans. Journal of Clinical Endocrinology and Metabolism 87 2988. (doi:10.1210/jc.87.6. 2988)

Gourcerol G \& Tache Y 2007 Obestatin - a ghrelin-associated peptide that does not hold its promise to suppress food intake and motility. Neurogastroenterology and Motility 19 161-165. (doi:10.1111/j.1365-2982.2007.00916.x)

Granata R, Settanni F, Trovato L, Destefanis S, Gallo D, Martinetti M, Ghigo E \& Muccioli G 2006 Unacylated as well as acylated ghrelin promotes cell survival and inhibit apoptosis in HIT-T15 pancreatic beta-cells. Journal of Endocrinological Investigation 29 RC19-RC22.

Granata R, Settanni F, Biancone L, Trovato L, Nano R, Bertuzzi F, Destefanis S, Annunziata M, Martinetti M, Catapano F et al. 2007 Acylated and unacylated ghrelin promote proliferation and inhibit apoptosis of pancreatic beta-cells and human islets: involvement of $3^{\prime}, 5^{\prime}$-cyclic adenosine monophosphate/protein kinase A, extracellular signal-regulated kinase $1 / 2$, and phosphatidyl inositol 3-kinase/Akt signaling. Endocrinology 148 512-529. (doi:10.1210/en.2006-0266)

Granata R, Settanni F, Gallo D, Trovato L, Biancone L, Cantaluppi V, Nano R, Annunziata M, Campiglia P, Arnoletti E et al. 2008 Obestatin promotes survival of pancreatic beta-cells and human islets and induces expression of genes involved in the regulation of beta-cell mass and function. Diabetes $\mathbf{5 7}$ 967-979. (doi:10.2337/db07-1104)

Granata R, Volante M, Settanni F, Gauna C, Ghé C, Annunziata M, Deidda B, Gesmundo I, Abribat T, van der Lely AJ et al. 2010 Unacylated ghrelin and obestatin increase islet cell mass and prevent diabetes in streptozotocin-treated newborn rats. Journal of Molecular Endocrinology 45 9-17. (doi:10.1677/JME09-0141) 
Gronberg M, Tsolakis AV, Magnusson L, Janson ET \& Saras J 2008 Distribution of obestatin and ghrelin in human tissues: immunoreactive cells in the gastrointestinal tract, pancreas, and mammary glands. Journal of Histochemistry and Cytochemistry 56 793-801. (doi:10.1369/jhc.2008.951145)

Gutierrez JA, Solenberg PJ, Perkins DR, Willency JA, Knierman MD, Jin Z, Witcher DR, Luo S, Onyia JE \& Hale JE 2008 Ghrelin octanoylation mediated by an orphan lipid transferase. PNAS 105 6320-6325. (doi:10.1073/pnas.0800708105)

Heller RS, Jenny M, Collombat P, Mansouri A, Tomasetto C, Madsen OD, Mellitzer G, Gradwohl G \& Serup P 2005 Genetic determinants of pancreatic epsilon-cell development. Developmental Biology 286 217-224. (doi:10.1016/j.ydbio.2005. 06.041)

Hill JT, Mastracci TL, Vinton C, Doyle ML, Anderson KR, Loomis ZL, Schrunk JM, Minic AD, Prabakar KR, Pugliese A et al. 2009 Ghrelin is dispensable for embryonic pancreatic islet development and differentiation. Regulatory Peptides 157 51-56. (doi:10. 1016/j.regpep.2009.02.013)

Hill JT, Chao CS, Anderson KR, Kaufman F, Johnson CW \& Sussel L $2010 \mathrm{Nkx2.2}$ activates the ghrelin promoter in pancreatic islet cells. Molecular Endocrinology 24 381-390. (doi:10.1210/me.2009-0360)

Holst B, Egerod KL, Schild E, Vickers SP, Cheetham S, Gerlach LO, Storjohann L, Stidsen CE, Jones R, Beck-Sickinger AG et al. 2007 GPR39 signaling is stimulated by zinc ions but not by obestatin. Endocrinology 148 13-20. (doi:10.1210/en. 2006-0933)

Holst B, Egerod KL, Jin C, Petersen PS, Ostergaard MV, Hald J, Sprinkel AM, Storling J, Mandrup-Poulsen T, Holst JJ et al. 2009 $\mathrm{G}$ protein-coupled receptor 39 deficiency is associated with pancreatic islet dysfunction. Endocrinology 150 2577-2585. (doi:10.1210/en.2008-1250)

Howard AD, Feighner SD, Cully DF, Arena JP, Liberator PA, Rosenblum CI, Hamelin M, Hreniuk DL, Palyha OC, Anderson $\mathrm{J}$ et al. 1996 A receptor in pituitary and hypothalamus that functions in growth hormone release. Science 273 974-977. (doi:10.1126/science.273.5277.974)

Inhoff T, Wiedenmann B, Klapp BF, Monnikes H \& Kobelt P 2009 Is desacyl ghrelin a modulator of food intake? Peptides $\mathbf{3 0}$ 991-994. (doi:10.1016/j.peptides.2009.01.019)

Irako T, Akamizu T, Hosoda H, Iwakura H, Ariyasu H, Tojo K, Tajima N \& Kangawa K 2006 Ghrelin prevents development of diabetes at adult age in streptozotocin-treated newborn rats. Diabetologia 49 1264-1273. (doi:10.1007/s00125-006-0226-3)

Iwakura H, Hosoda K, Son C, Fujikura J, Tomita T, Noguchi M, Ariyasu H, Takaya K, Masuzaki H, Ogawa Y et al. 2005 Analysis of rat insulin II promoter-ghrelin transgenic mice and rat glucagon promoter-ghrelin transgenic mice. Journal of Biological Chemistry 280 15247-15256. (doi:10.1074/jbc.M411358200)

Jhala US, Canettieri G, Screaton RA, Kulkarni RN, Krajewski S, Reed J, Walker J, Lin X, White M \& Montminy M 2003 cAMP promotes pancreatic beta-cell survival via CREB-mediated induction of IRS2. Genes and Development 17 1575-1580. (doi:10.1101/gad.1097103)

Kageyama H, Funahashi H, Hirayama M, Takenoya F, Kita T, Kato S, Sakurai J, Lee EY, Inoue S, Date Y et al. 2005 Morphological analysis of ghrelin and its receptor distribution in the rat pancreas. Regulatory Peptides 126 67-71. (doi:10.1016/j.regpep. 2004.08.031)

Kerem M, Salman B, Ozsoy S, Pasaoglu H, Bedirli A, Haziroglu R \& Yilmaz TU 2009 Exogenous ghrelin enhances endocrine and exocrine regeneration in pancreatectomized rats. Journal of Gastrointestinal Surgery 13 775-783. (doi:10.1007/s11605-0080778-2)

Kim SW, Her SJ, Park SJ, Kim D, Park KS, Lee HK, Han BH, Kim MS, Shin CS \& Kim SY 2005 Ghrelin stimulates proliferation and differentiation and inhibits apoptosis in osteoblastic MC3T3-E1 cells. Bone 37 359-369. (doi:10.1016/j.bone.2005. 04.020)

Kojima M, Hosoda H, Date Y, Nakazato M, Matsuo H \& Kangawa K 1999 Ghrelin is a growth-hormone-releasing acylated peptide from stomach. Nature 402 656-660. (doi:10.1038/45230)

van der Lely AJ 2009 Ghrelin and new metabolic frontiers. Hormone Research 71 (Supplement 1) 129-133. (doi:10.1159/ 000178055)

van der Lely AJ, Tschop M, Heiman ML \& Ghigo E 2004 Biological, physiological, pathophysiological, and pharmacological aspects of ghrelin. Endocrine Reviews 25 426-457. (doi:10.1210/er.20020029)

Mandrup-Poulsen T $2001 \beta$-Cell apoptosis: stimuli and signaling. Diabetes 50 (Supplement 1) S58-S63. (doi:10.2337/diabetes.50. 2007.S58)

McCabe C, Samali A \& O'Brien T $2006 \beta$-Cell cytoprotective strategies: establishing the relative roles for iNOS and ROS. Biochemical and Biophysical Research Communications 342 1240-1248. (doi:10.1016/j.bbrc.2006.02.092)

Montrose-Rafizadeh C, Avdonin P, Garant MJ, Rodgers BD, Kole S, Yang H, Levine MA, Schwindinger W \& Bernier M 1999 Pancreatic glucagon-like peptide-1 receptor couples to multiple $\mathrm{G}$ proteins and activates mitogen-activated protein kinase pathways in Chinese hamster ovary cells. Endocrinology 140 1132-1140. (doi:10.1210/en.140.3.1132)

Muccioli G, Baragli A, Granata R, Papotti M \& Ghigo E 2007 Heterogeneity of ghrelin/growth hormone secretagogue receptors. Toward the understanding of the molecular identity of novel ghrelin/GHS receptors. Neuroendocrinology 86 147-164. (doi:10.1159/000105141)

Oliver-Krasinski JM, Kasner MT, Yang J, Crutchlow MF, Rustgi AK, Kaestner KH \& Stoffers DA 2009 The diabetes gene Pdxl regulates the transcriptional network of pancreatic endocrine progenitor cells in mice. Journal of Clinical Investigation 119 1888-1898. (doi:10.1172/JCI37028)

Park S, Dong X, Fisher TL, Dunn S, Omer AK, Weir G \& White MF 2006 Exendin-4 uses Irs2 signaling to mediate pancreatic beta cell growth and function. Journal of Biological Chemistry 281 1159-1168. (doi:10.1074/jbc.M508307200)

Pazos Y, Alvarez CJ, Camina JP, Al-Massadi O, Seoane LM \& Casanueva FF 2009 Role of obestatin on growth hormone secretion: an in vitro approach. Biochemical and Biophysical Research Communications 390 1377-1381. (doi:10.1016/j.bbrc. 2009.10.163)

Prado CL, Pugh-Bernard AE, Elghazi L, Sosa-Pineda B \& Sussel L 2004 Ghrelin cells replace insulin-producing beta cells in two mouse models of pancreas development. PNAS 101 2924-2929. (doi:10.1073/pnas.0308604100)

Qader SS, Lundquist I, Ekelund M, Hakanson R \& Salehi A 2005 Ghrelin activates neuronal constitutive nitric oxide synthase in pancreatic islet cells while inhibiting insulin release and stimulating glucagon release. Regulatory Peptides 128 51-56. (doi:10.1016/j.regpep.2004.12.018)

Qader SS, Hakanson R, Rehfeld JF, Lundquist I \& Salehi A 2008 Proghrelin-derived peptides influence the secretion of insulin, glucagon, pancreatic polypeptide and somatostatin: a study on isolated islets from mouse and rat pancreas. Regulatory Peptides 146 230-237. (doi:10.1016/j.regpep.2007.09.017)

Ragvin A, Moro E, Fredman D, Navratilova P, Drivenes $\varnothing$, Engström PG, Alonso ME, Mustienes Ede L, Skarmeta JL, Tavares MJ et al. 2010 Long-range gene regulation links genomic type 2 diabetes and obesity risk regions to HHEX, SOX4, and IRX3. PNAS 107 775-780. (doi:10.1073/pnas. 0911591107)

Reimer MK, Pacini G \& Ahren B 2003 Dose-dependent inhibition by ghrelin of insulin secretion in the mouse. Endocrinology 144 916-921. (doi:10.1210/en.2002-220819) 
Ren AJ, Guo ZF, Wang YK, Lin L, Zheng X \& Yuan WJ $2008 a$ Obestatin, obesity and diabetes. Peptides 30 439-444. (doi:10. 1016/j.peptides.2008.10.002)

Ren AJ, Guo ZF, Wang YK, Wang LG, Wang WZ, Lin L, Zheng X \& Yuan WJ $2008 b$ Inhibitory effect of obestatin on glucoseinduced insulin secretion in rats. Biochemical and Biophysical Research Communications 369 969-972. (doi:10.1016/j.bbrc. 2008.02.146)

Salehi A, Dornonville de la Cour C, Hakanson R \& Lundquist I 2004 Effects of ghrelin on insulin and glucagon secretion: a study of isolated pancreatic islets and intact mice. Regulatory Peptides 118 143-150. (doi:10.1016/j.regpep.2003.12.001)

Samson SL \& Chan L 2006 Gene therapy for diabetes: reinventing the islet. Trends in Endocrinology and Metabolism 17 92-100. (doi:10.1016/j.tem.2006.02.002)

Soares JB \& Leite-Moreira AF 2008 Ghrelin, des-acyl ghrelin and obestatin: three pieces of the same puzzle. Peptides 29 1255-1270. (doi:10.1016/j.peptides.2008.02.018)

Soyer J, Flasse L, Raffelsberger W, Beucher A, Orvain C, Peers B, Ravassard P, Vermot J, Voz ML, Mellitzer G et al. 2010 Rfx6 is an Ngn3-dependent winged helix transcription factor required for pancreatic islet cell development. Development 137 203-212. (doi:10.1242/dev.041673)

Sun Y, Wang P, Zheng H \& Smith RG 2004 Ghrelin stimulation of growth hormone release and appetite is mediated through the growth hormone secretagogue receptor. PNAS 101 4679-4684. (doi:10.1073/pnas.0305930101)

Sun Y, Asnicar M \& Smith RG 2007 Central and peripheral roles of ghrelin on glucose homeostasis. Neuroendocrinology 86 215-228. (doi:10.1159/000109094)

Tang SQ, Jiang QY, Zhang YL, Zhu XT, Shu G, Gao P, Feng DY, Wang XQ \& Dong XY 2008 Obestatin: its physicochemical characteristics and physiological functions. Peptides 29 639-645. (doi:10.1016/j.peptides.2008.01.012)

Terauchi Y, Takamoto I, Kubota N, Matsui J, Suzuki R, Komeda K, Hara A, Toyoda Y, Miwa I, Aizawa S et al. 2007 Glucokinase and IRS-2 are required for compensatory beta cell hyperplasia in response to high-fat diet-induced insulin resistance. Journal of Clinical Investigation 117 246-257. (doi:10.1172/JCI17645)

Tremblay F, Richard AM, Will S, Syed J, Stedman N, Perreault M \& Gimeno RE 2009 Disruption of $\mathrm{G}$ protein-coupled receptor 39 impairs insulin secretion in vivo. Endocrinology 150 2586-2595. (doi:10.1210/en.2008-1251)

Ueberberg B, Unger N, Saeger W, Mann K \& Petersenn S 2009 Expression of ghrelin and its receptor in human tissues. Hormone and Metabolic Research 41 814-821. (doi:10.1055/ s-0029-1233462)

Unniappan S, Speck M \& Kieffer TJ 2008 Metabolic effects of chronic obestatin infusion in rats. Peptides 29 1354-1361. (doi:10.1016/j.peptides.2008.03.023)

Volante M, Allia E, Gugliotta P, Funaro A, Broglio F, Deghenghi R, Muccioli G, Ghigo E \& Papotti M 2002 Expression of ghrelin and of the GH secretagogue receptor by pancreatic islet cells and related endocrine tumors. Journal of Clinical Endocrinology and Metabolism 87 1300-1308. (doi:10.1210/jc.87.3.1300)

Volante M, Rosas R, Ceppi P, Rapa I, Cassoni P, Wiedenmann B, Settanni F, Granata R \& Papotti M 2009 Obestatin in human neuroendocrine tissues and tumours: expression and effect on tumour growth. Journal of Pathology 218 458-466. (doi:10.1002/ path.2551)
Walia P, Asadi A, Kieffer TJ, Johnson JD \& Chanoine JP 2009 Ontogeny of ghrelin, obestatin, preproghrelin, and prohormone convertases in rat pancreas and stomach. Pediatric Research 65 39-44. (doi:10.1203/PDR.0b013e31818bc134)

Wang Q, Elghazi L, Martin S, Martins I, Srinivasan RS, Geng X, Sleeman M, Collombat P, Houghton J \& Sosa-Pineda B 2008 Ghrelin is a novel target of Pax4 in endocrine progenitors of the pancreas and duodenum. Developmental Dynamics 237 51-61. (doi:10.1002/dvdy.21379)

Wang W, Liu Y, Chen Y, Cao C, Xiang Y, Zhang D, Han L, Zhao H \& Liu G $2010 a$ Inhibition of Foxol mediates protective effects of ghrelin against lipotoxicity in MIN6 pancreatic beta-cells. Peptides 31 307-314. (doi:10.1016/j.peptides.2009.11.011)

Wang W, Zhang D, Zhao H, Chen Y, Liu Y, Cao C, Han L \& Liu G $2010 b$ Ghrelin inhibits cell apoptosis induced by lipotoxicity in pancreatic beta-cell line. Regulatory Peptides 161 43-50. (doi:10. 1016/j.regpep.2009.12.017)

Wierup N \& Sundler F 2005 Ultrastructure of islet ghrelin cells in the human fetus. Cell and Tissue Research 319 423-428. (doi:10. 1007/s00441-004-1044-x)

Wierup N, Svensson H, Mulder H \& Sundler F 2002 The ghrelin cell: a novel developmentally regulated islet cell in the human pancreas. Regulatory Peptides 107 63-69. (doi:10.1016/S01670115(02)00067-8)

Wierup N, Yang S, McEvilly RJ, Mulder H \& Sundler F 2004 Ghrelin is expressed in a novel endocrine cell type in developing rat islets and inhibits insulin secretion from INS-1 (832/13) cells. Journal of Histochemistry and Cytochemistry 52 301-310.

Yamamoto H, Uchigata Y \& Okamoto H 1981 Streptozotocin and alloxan induce DNA strand breaks and poly(ADP-ribose) synthetase in pancreatic islets. Nature 294 284-286. (doi:10. 1038/294284a0)

Yang J, Brown MS, Liang G, Grishin NV \& Goldstein JL 2008 Identification of the acyltransferase that octanoylates ghrelin, an appetite-stimulating peptide hormone. Cell 132 387-396. (doi:10.1016/j.cell.2008.01.017)

Zhang JV, Ren PG, Avsian-Kretchmer O, Luo CW, Rauch R, Klein C \& Hsueh AJ 2005 Obestatin, a peptide encoded by the ghrelin gene, opposes ghrelin's effects on food intake. Science $\mathbf{3 1 0}$ 996-999. (doi:10.1126/science.1117255)

Zhang Y, Ying B, Shi L, Fan H, Yang D, Xu D, Wei Y, Hu X, Zhang Y, Zhang X et al. 2007 Ghrelin inhibit cell apoptosis in pancreatic beta cell line HIT-T15 via mitogen-activated protein kinase/ phosphoinositide 3-kinase pathways. Toxicology 237 194-202. (doi:10.1016/j.tox.2007.05.013)

Zhang JV, Jahr H, Luo CW, Klein C, Van Kolen K, Ver Donck L, De A, Baart E, Li J, Moechars D et al. 2008 Obestatin induction of early-response gene expression in gastrointestinal and adipose tissues and the mediatory role of $G$ proteincoupled receptor, GPR39. Molecular Endocrinology 22 1464-1475. (doi:10.1210/me.2007-0569)

Zhao CM, Furnes MW, Stenstrom B, Kulseng B \& Chen D 2008 Characterization of obestatin- and ghrelin-producing cells in the gastrointestinal tract and pancreas of rats: an immunohistochemical and electron-microscopic study. Cell and Tissue Research 331 575-587. (doi:10.1007/s00441-007-0514-3)

Received in final form 28 June 2010

Accepted 1 July 2010

Made available online as an Accepted Preprint 1 July 2010 